\title{
One-step immunopurification and lectinochemical characterization of the Duffy atypical chemokine receptor from human erythrocytes
}

\author{
Magdalena Grodecka • Olivier Bertrand • \\ Ewa Karolak • Marek Lisowski • \\ Kazimiera Waśniowska
}

Received: 21 October 2011 /Revised: 7 December 2011 / Accepted: 18 December 2011/Published online: 14 January 2012

(C) The Author(s) 2012. This article is published with open access at Springerlink.com

\begin{abstract}
Duffy antigen/receptor for chemokines (DARC) is a glycosylated seven-transmembrane protein acting as a blood group antigen, a chemokine binding protein and a receptor for Plasmodium vivax malaria parasite. It is present on erythrocytes and endothelial cells of postcapillary venules. The N-terminal extracellular domain of the Duffy glycoprotein carries $\mathrm{Fy}^{\mathrm{a}} / \mathrm{Fy}^{\mathrm{b}}$ blood group antigens and Fy6 linear epitope recognized by monoclonal antibodies. Previously, we have shown that recombinant Duffy protein expressed in K562 cells has three $\mathrm{N}$-linked oligosaccharide chains, which are mainly of complex-type. Here we report a
\end{abstract}

M. Grodecka • E. Karolak • K. Waśniowska $(\square)$

Department of Immunochemistry, Ludwik Hirszfeld Institute of Immunology and Experimental Therapy,

Polish Academy of Sciences,

R. Weigla 12,

53-114 Wrocław, Poland

e-mail: wasniows@iitd.pan.wroc.pl

O. Bertrand

Institut National de la Santé et de la Recherche Médicale,

UMR_S 665,

F-75015 Paris, France

O. Bertrand

Institut National de la Transfusion Sanguine,

F-75015 Paris, France

M. Lisowski

Faculty of Chemistry, University of Wrocław,

F. Joliot-Curie 14,

50-383 Wrocław, Poland

K. Waśniowska

Faculty of Physical Education and Physiotherapy,

Opole University of Technology,

Prószkowska 76,

45-758 Opole, Poland one-step purification method of Duffy protein from human erythrocytes. DARC was extracted from erythrocyte membranes in the presence of $1 \% n$-dodecyl- $\beta$-D-maltoside (DDM) and $0.05 \%$ cholesteryl hemisuccinate (CHS) and purified by affinity chromatography using immobilized anti-Fy 6 $2 \mathrm{C} 3$ mouse monoclonal antibody. Duffy glycoprotein was eluted from the column with synthetic DFEDVWN peptide containing epitope for $2 \mathrm{C} 3$ monoclonal antibody. In this single-step immunoaffinity purification method we obtained highly purified DARC, which migrates in SDS-polyacrylamide gel as a major diffuse band corresponding to a molecular mass of 40-47 $\mathrm{kDa}$. In ELISA purified Duffy glycoprotein binds anti-Duffy antibodies recognizing epitopes located on distinct regions of the molecule. Results of circular dichroism measurement indicate that purified DARC has a high content of $\alpha$ helical secondary structure typical for chemokine receptors. Analysis of DARC glycans performed by means of lectin blotting and glycosidase digestion suggests that native Duffy $\mathrm{N}$-glycans are mostly triantennary complex-type, terminated with $\alpha 2-3$ - and $\alpha 2-6$-linked sialic acid residues with bisecting GlcNAc and $\alpha 1-6$-linked fucose at the core.

Keywords Duffy antigen · Immunopurification . Chemokine receptor $\cdot$ Glycoproteomics $\cdot N$-glycans $\cdot$ Lectins

$\begin{array}{ll}\text { Abbreviations } \\ \text { BCA } & \begin{array}{l}\text { Bicinchoninic acid } \\ \text { BCIP }\end{array} \\ & \begin{array}{l}\text { 5-bromo-4-chloro-3-indolyl phosphate } \\ \text { p-toluidine salt }\end{array} \\ \text { BSA } & \text { Bovine serum albumin } \\ \text { CHS } & \text { Cholesteryl hemisuccinate } \\ \text { DDM } & n \text {-dodecyl- } \beta \text {-D-maltoside } \\ \text { EDTA } & \text { Ethylenediaminetetraacetic acid } \\ \text { ELISA } & \text { Enzyme-linked immunosorbent assay }\end{array}$




$\begin{array}{ll}\text { NBT } & \text { p-nitro blue tetrazolium chloride } \\ \text { PBS } & \text { Phosphate buffered saline } \\ \text { PMSF } & \text { Phenylmethanesulfonyl fluoride } \\ \text { PNGase F } & \text { Peptide } N \text {-glycosidase F } \\ \text { MoAb } & \text { Monoclonal antibody } \\ \text { RBC } & \text { Red blood cells } \\ \text { SDS-PAGE } & \begin{array}{l}\text { Sodium dodecyl sulfate polyacrylamide } \\ \text { gel electrophoresis }\end{array} \\ \text { TBS } & \text { Tris-buffered saline } \\ \text { TTBS } & 0.05 \% \text { Tween-20 in TBS }\end{array}$

\section{Introduction}

Duffy antigen is a transmembrane $N$-glycosylated protein present mainly on erythrocytes and endothelial cells of postcapillary venules of various tissues. Initially identified as a blood group antigen, it was later characterized as a receptor for Plasmodium vivax parasites and a promiscuous chemokine-binding protein.

The polypeptide chain of the Duffy glycoprotein consists of 336 amino-acid residues and spans cell membrane seven times, creating three extra- and three intracellular loops. The N-terminal glycosylated extracellular domain of DARC carries the $\mathrm{Fy}^{\mathrm{a}}$ and $\mathrm{Fy}^{\mathrm{b}}$ Duffy blood group antigens, which differ by an amino acid at position $42\left(\mathrm{Fy}^{\mathrm{a}}-\mathrm{Gly}, \mathrm{Fy}^{\mathrm{b}}-\mathrm{Asp}\right)$, but have a common Fy6 epitope [1-3]. The Fy6 epitopes, recognized by a number of monoclonal antibodies, are located within sequence ${ }^{19}$ QLDFEDVW ${ }^{26}$ of the Duffy polypeptide chain. Another common antigenic determinant Fy3 is located on the third extracellular loop of the polypeptide chain of Duffy glycoprotein [4-6]. The extracellular domain of DARC is particularly interesting because it is involved in the interaction with chemokines and P. vivax parasite [7-10].

Duffy antigen acts as a promiscuous receptor for a number of pro-inflammatory CC and CXC chemokines, therefore it is called the Duffy antigen/receptor for chemokines (DARC) [7, 11]. Although structurally related to functional chemokine receptors, it lacks the DRYLAIV motif on the second intracellular loop and does not participate in Gprotein dependent signal transduction. For this reason it was designated as a "silent" chemokine receptor or, more recently, as a member of the atypical chemokine receptors (ACR) family [12-15]. DARC is an important regulator of inflammatory reactions, acting as a chemokine scavenger on the surface of red blood cells, and expressed in endothelial cells, as a regulator of induced leukocyte trafficking [16, 17]. It is postulated that it plays a protective role in cancer formation and development by inhibiting angiogenesis of the tumor tissue and metastasis [18, 19]. DARC might participate in post-transplant inflammation of the kidney, leading to graft rejection [20].
The role of the Duffy antigen is only partially elucidated. A more detailed biophysical and structural characterization is essential for understanding its various functions. To date, the structure of Duffy glycoprotein has not been characterized due to difficulties in obtaining purified Duffy protein. Several attempts have been made to purify the Duffy antigen from human red blood cells [21-24], however, with only limited success.

DARC is a sialylated glycoprotein containing $N$-linked oligosaccharides, which has a strong tendency to form aggregates, even under denaturing conditions, and migrates in polyacrylamide gel as a wide $36-47 \mathrm{kDa}$ band $[22,25,26]$. We have previously shown that DARC expressed in K562 cells is a glycoprotein with three $N$-linked oligosaccharide chains, which are mostly of complex-type, rich in $\mathrm{N}$-acetyllactosamine units terminating with $\alpha 2$-6-linked sialic acid residues, with $\alpha 1$-6-fucose at the $N, N^{\prime}$-diacetylchitobiose core $[27,28]$. The aim of our present study was to develop a procedure to purify the native DARC molecule from human erythrocytes and to characterize the structure of its sugar chains. Immunoaffinity purification using immobilized monoclonal anti-Duffy antibody and synthetic peptide containing epitope sequence for elution was considered to be the most promising [29]. Here we describe the solubilization and immunopurification of the DARC from human erythrocyte membranes and the characterization of its $N$-linked oligosaccharide chains. This is the first detailed study addressing the purification and molecular characterization of the human DARC and the structure of its $N$-glycan chains.

\section{Materials and methods}

\section{Monoclonal antibodies}

The following monoclonal antibodies, which epitopes were characterized in our laboratory, were used: mouse anti-Fy6 i3A and 2C3 [4, 5], anti-GPA 4E4 [30], anti-Band3 136 [31], anti-Fy3 MIMA29, and human anti-Fy ${ }^{\mathrm{a}} 5 \mathrm{~T} 72$ [6].

Preparation of the anti-Duffy immunoaffinity column

To purify anti-Duffy antibody, hybridoma cells producing anti-Fy6 2C3 monoclonal antibody were cultured in BD Cell MAb Serum-Free Medium supplemented with $2 \mathrm{mM}$ GlutaMAX in BD CELLine 1000 system (BD Biosciences) according to the manufacturer's instructions. Adapted cells grown in this medium remained living and were capable of producing the $2 \mathrm{C} 3$ antibody for $8-10$ weeks. This allowed us to obtain $\sim 120 \mathrm{mg}$ of $2 \mathrm{C} 3 \mathrm{MoAb}$, which was then purified on Pierce Protein G Agarose (Pierce) and immobilized on agarose beads using AminoLink plus Immobilization Kit (Pierce) according to the manufacturer's 
instructions. One hundred milligrams of purified $2 \mathrm{C} 3 \mathrm{MoAb}$ was immobilized on $10 \mathrm{ml}$ of AminoLink resin with a coupling efficiency of $98.2 \%$. Anti-Fy6 resin was stored in PBS containing $0.05 \%$ sodium azide at $4{ }^{\circ} \mathrm{C}$.

Preparation of the human erythrocyte ghosts

Human erythrocytes from outdated blood units were obtained from the Regional Centre of Transfusion Medicine and Blood Bank, Wrocław, Poland. Erythrocyte ghosts were prepared from red blood cells using a modification of the method of Steck et al. [32]. Briefly, red blood cells were lysed in 10 volumes of ice-cold $5 \mathrm{mM}$ phosphate buffer $\mathrm{pH} 8.0$ in the presence of $1 \mathrm{mM}$ EDTA and $0.2 \mathrm{mM}$ PMSF (Sigma) for $10 \mathrm{~min}$. Erythrocyte membranes were isolated by recirculating the lysate in Pellicon Biomax Coarse $0.5 \mathrm{~m}^{2}$ tangential flow cassette (pore size $1,000 \mathrm{kDa}$; Millipore) in $5 \mathrm{mM}$ phosphate buffer $\mathrm{pH}$ 8.0, $1 \mathrm{mM}$ EDTA, $0.2 \mathrm{mM}$ PMSF at $4{ }^{\circ} \mathrm{C}$ until complete removal of the hemoglobin [33]. The washed ghosts were concentrated by centrifugation at $14,000 \times \mathrm{g}$ for $45 \mathrm{~min}$ and stored at $-80^{\circ} \mathrm{C}$ with protease inhibitors: $5 \mu \mathrm{g} / \mathrm{ml}$ aprotinin, $5 \mu \mathrm{g} / \mathrm{ml}$ leupeptin, $0.1 \mathrm{mM}$ Pefabloc (Roche) until further use.

Purification of the Duffy glycoprotein from human erythrocytes

All purification steps were performed at $4^{\circ} \mathrm{C}$ in the presence of protease inhibitors $(5 \mu \mathrm{g} / \mathrm{ml}$ aprotinin, $5 \mu \mathrm{g} / \mathrm{ml}$ leupeptin and $0.1 \mathrm{mM}$ Pefabloc). Erythrocyte ghosts $(200 \mathrm{ml})$ were solubilized by incubation with an equal volume of $50 \mathrm{mM}$ Tris- $\mathrm{HCl} \mathrm{pH} \mathrm{7.4,} \mathrm{containing} 300 \mathrm{mM} \mathrm{NaCl}, 20 \%$ glycerol, $2 \%$ DDM and $0.1 \%$ CHS (Sigma) for $4 \mathrm{~h}$ on a rotator and centrifuged at $27,000 \times g, 45 \mathrm{~min}$ to remove the insolubilized debris. The solubilized ghosts were incubated with $6 \mathrm{ml}$ of resin with immobilized $2 \mathrm{C} 3$ antibody overnight at $4^{\circ} \mathrm{C}$ on a rotator. After overnight incubation the resin was centrifuged at $150 \times g$ for $5 \mathrm{~min}$ to separate the supernatant and the resin was transferred into a $20 \times 1.5 \mathrm{~cm}$ glass column. The column was washed with 20 volumes of equilibration buffer $25 \mathrm{mM}$ Tris- $\mathrm{HCl} \mathrm{pH} 7.4,150 \mathrm{mM} \mathrm{NaCl}, 10 \%$ glycerol, $0.1 \%$ DDM, $0.005 \%$ CHS and bound Duffy protein was eluted from the column with 10 column volumes of $300 \mu \mathrm{g} / \mathrm{ml}$ of DFEDVWN custom synthetic peptide (Mimotopes) in equilibration buffer. Then the column was washed with five column volumes of $0.1 \mathrm{M}$ glycine $\mathrm{pH} 2.8$, five column volumes of $50 \mathrm{mM}$ diethylamine $\mathrm{pH} 11$, containing $0.5 \mathrm{M} \mathrm{NaCl}, 0.1 \%$ DDM, $10 \%$ glycerol, $1 \mathrm{mM}$ Pefabloc, and finally with 20 volumes of equilibration buffer. All eluates were checked for the presence of Duffy glycoprotein by western blotting using $2 \mathrm{C} 3$ antibody and Duffy-positive fractions were combined. The DFEDVWN peptide was removed from purified Duffy glycoprotein samples using
Zeba Spin Desalting Columns (Thermo Scientific) according to manufacturer's instructions. Protein concentration was determined using Picodrop spectrophotometer (Picodrop Limited) and BCA assay [34]. Purified Duffy glycoprotein was subjected to molecular characterization and oligosaccharide chain analysis as described below.

\section{Circular dichroism measurements}

The CD spectroscopy was carried out on a Jasco J-600 spectropolarimeter (JASCO) with a $1 \mathrm{~mm}$ path length cell cuvette at room temperature. The measurements were performed on immunopurified Duffy glycoprotein at $4.33 \mu \mathrm{M}$ concentration in $0.05 \%$ DDM in PBS. The CD spectrum which is given, is the mean of three scans.

\section{ELISA measurements}

Wells of MaxiSorp white opaque plates (Nunc) were coated with $50 \mu$ of purified DARC $(2 \mu \mathrm{g} / \mathrm{ml})$ in $60 \mathrm{mM} \mathrm{NaHCO}_{3}$ $\mathrm{pH} 9.6$ overnight at $4^{\circ} \mathrm{C}$. All subsequent steps were performed at room temperature. The wells were blocked with $200 \mu \mathrm{l}$ of $2 \%$ BSA, $0.1 \%$ Tween- 20 in TBS for $1 \mathrm{~h}$, washed with $3 \times 200 \mu \mathrm{l}$ of TTBS and were subsequently incubated for $2 \mathrm{~h}$ with $50 \mu \mathrm{l}$ of monoclonal anti-Duffy or anti-GPA antibody serially diluted in TTBS and then for $1 \mathrm{~h}$ with $50 \mu \mathrm{l}$ of anti-mouse IgG or anti-human IgG antibody conjugated with horseradish peroxidase (HRP; Bio-Rad) diluted in TTBS. After each incubation the wells were washed with $5 \times 200 \mu \mathrm{l}$ of TTBS. A chemiluminescent reaction was developed with $50 \mu \mathrm{l}$ of SuperSignal ELISA Pico Chemiluminescent Substrate (Thermo Scientific) and measured using Victor Light Luminescence Plate Reader (Perkin Elmer). All tests were performed in duplicate.

\section{SDS-PAGE and western blotting}

Protein samples were incubated in SDS sample buffer at room temperature for $10 \mathrm{~min}$ and subjected to electrophoresis in $12 \%$ polyacrylamide gels according to Laemmli [35]. Following electrophoresis the gels were either stained with $0.25 \%$ Coomassie Brilliant Blue R250 (Bio-Rad) [36] or proteins were electrophoretically transferred to Immobilon-P membrane (Millipore) [37]. The blots were blocked for $4 \mathrm{~h}$ at room temperature with 5\% low-fat milk (Bio-Rad), 0.3\% Tween-20 in TBS pH 7.4. Blotted Duffy protein was identified by consecutive incubations with anti-Fy6 $2 \mathrm{C} 3$ monoclonal antibody (overnight at $4{ }^{\circ} \mathrm{C}$ ), alkaline phosphatase-conjugated goat anti-mouse $\operatorname{IgG}$ antibody (Bio-Rad; $1 \mathrm{~h}$, room temperature), and phosphatase substrate solution: $0.15 \mathrm{mg} / \mathrm{ml} \mathrm{BCIP}$ and $0.3 \mathrm{mg} / \mathrm{ml} \mathrm{NBT}$ (Bio-Rad) in $0.1 \mathrm{M}$ Tris- $\mathrm{HCl} \mathrm{pH} 9.5,1 \mathrm{mM} \mathrm{MgCl}$ buffer. After each step the blots were washed $5 \times 7$ min with TTBS 
$\mathrm{pH}$ 7.4. The gels and the blots were photographed with G:Box imaging system (Syngene).

\section{Lectin blotting}

Purified Duffy glycoprotein was subjected to SDS-PAGE and transferred to Immobilon-P membrane. The membrane was incubated overnight at $4^{\circ} \mathrm{C}$ in $0.5 \%$ Tween-20 in TBS. Later the blots were incubated with digoxigenin-labeled lectins Datura stramonium agglutinin (DSA), Galanthus nivalis agglutinin (GNA), Sambucus nigra agglutinin (SNA), and Maackia amurensis agglutinin (MAA; DIG Glycan Differentiation Kit, Roche) $1 \mu \mathrm{g} / \mathrm{ml}$ each or biotinlabeled lectins Aleuria aurantia agglutinin (AAA), Canavalia ensiformis agglutinin (ConA), Dolichos biflorus agglutinin (DBA), Griffonia simplicifolia I B $_{4}$ lectin (GSL-I $\left.\mathrm{B}_{4}\right)$, Griffonia simplicifolia II lectin (GSL-II), Lens culinaris agglutinin (LCA), Phaseolus vulgaris erythroagglutinin (PHA-E), Phaseolus vulgaris leukoagglutinin (PHA-L), Pisum sativum agglutinin (PSA), Psathyrella velutina agglutinin (PVA), Ricinus communis I agglutinin (RCA-I), Glycine max agglutinin (soybean, SBA), Ulex europaeus agglutinin (UEA), Wisteria floribunda agglutinin (WFA), Triticum vulgaris agglutinin (wheat germ, WGA; Vector Laboratories) $5 \mu \mathrm{g} / \mathrm{ml}$ each in $0.5 \%$ Tween-20/TBS pH 7.4 or $\mathrm{pH} 8.0$ for AAA, with $1 \mathrm{mM} \mathrm{MgCl} 2,1 \mathrm{mM} \mathrm{MnCl}_{2}, 1 \mathrm{mM}$ $\mathrm{CaCl}_{2}$ and $0.5 \mathrm{M} \mathrm{NaCl}$ for WGA. Incubation was performed at room temperature for $2 \mathrm{~h}$ with gentle shaking. The blots were washed $5 \times 10$ min with $0.5 \%$ Tween- 20 in TBS and $1 \times 10$ min with $0.1 \%$ Tween-20 in TBS, and incubated with either anti-digoxigenin-alkaline phosphatase conjugate 1,000-fold diluted (Roche) or alkaline phosphataseconjugated streptavidin 1,000-fold diluted (Vector Laboratories) in $0.1 \%$ Tween-20 in TBS for $1 \mathrm{~h}$ at room temperature with gentle shaking. After washing the blots $4 \times 10 \mathrm{~min}$ with $0.1 \%$ Tween-20 in TBS and $2 \times 10$ min with TBS, color reaction was developed using standard BCIP/NBT conditions.

The specificity of selected lectins binding was verified by using lectins preincubated for $2 \mathrm{~h}$ at room temperature in buffer containing 0.7 M L-fucose (for AAA; Sigma), $0.5 \mathrm{M}$ $\alpha$-methyl-D-mannopyranoside (for LCA; Sigma), $0.5 \mathrm{M}$ galactose (for RCA-I; Merck) and $0.5 \mathrm{M} \mathrm{N}$-acetylglycosamine (for WGA; Sigma). The specificities of MAA, SNA, RCA-I, GSL-II and PVL were studied by their reaction with the blotted Duffy protein after consecutive removal of sialic acid and galactose residues. The lectins and their specificities are listed in Table 1.

Modification of the blotted glycoproteins

Desialylation was performed by incubating the blots after protein transfer with $0.025 \mathrm{M}$ sulfuric acid for $1 \mathrm{~h}$ at $80^{\circ} \mathrm{C}$.
Degalactosylation was performed after desialylation by incubating the blots successively in (i) $0.05 \mathrm{M} \mathrm{NaIO}_{4}$ in $0.1 \mathrm{M}$ acetate buffer, $\mathrm{pH} 4.5$, overnight at $4^{\circ} \mathrm{C}$, (ii) $0.15 \mathrm{M} \mathrm{NaBH}_{4}$ in $0.1 \mathrm{M}$ sodium borate buffer, $\mathrm{pH} 8.0$, for $2-3 \mathrm{~h}$ at $20^{\circ} \mathrm{C}$, and (iii) $0.025 \mathrm{M}$ sulfuric acid for $1 \mathrm{~h}$ at $80^{\circ} \mathrm{C}$. Each incubation was followed by washing the blots with water [38]. After modification, the blots were blocked and analyzed by lectin binding.

Endo- and exoglycosidase digestion

Glycosidase digestions were performed following protocols provided by the enzyme suppliers. Before enzyme treatment, the buffer in Duffy samples was changed to digestion buffer using Zeba Spin Desalting Columns (Thermo Scientific). Duffy protein was incubated overnight at $37^{\circ} \mathrm{C}$ with: PNGase F, endo- $\beta$-galactosidase, endoglycosidases F1, F2 and F3 (Sigma, Calbiochem) and neuraminidases from Newcastle disease virus (NDV; Genzyme) or from Arthrobacter ureafaciens (ABS; Sigma) in the presence of protease inhibitors Complete, EDTA-free Protease Inhibitor Cocktail Tablets (Roche) and Protease Inhibitor Cocktail (Sigma). The reaction was terminated by chilling the samples at $4^{\circ} \mathrm{C}$ and adding Laemmli electrophoresis sample buffer [35]. Digested glycoprotein was analyzed by immunoblotting.

\section{Results}

Purification of the human DARC by anti-Fy6 affinity chromatography

In order to isolate Duffy glycoprotein from human erythrocyte membranes, several detergent mixtures were tested. Similarly to other chemokine receptors $[28,39-41]$ a combination of $1 \%$ DDM and $0.05 \%$ CHS was found to be optimal for solubilizing and stabilizing the Duffy protein. Duffy antigen was retained from the ghost detergent extract on the immobilized $2 \mathrm{C} 3 \mathrm{MoAb}$ column. It was eluted in three to five column volumes during development with mobile phase containing DFEDVWN peptide. Only a small amount of Duffy antigen was eluted from the column with $50 \mathrm{mM}$ diethylamine, $0.5 \mathrm{M} \mathrm{NaCl}, 0.1 \%$ DDM, $10 \%$ glycerol, $1 \mathrm{mM}$ Pefabloc $\mathrm{pH} 11$ or $0.1 \mathrm{M}$ glycine $\mathrm{pH} 2.8$. This indicates that elution with DFEDVWN peptide solution in the column buffer is highly efficient and nearly complete. Starting with $200 \mathrm{ml}$ of erythrocyte membranes containing $\sim 800 \mathrm{mg}$ of total protein we routinely obtained ca. $500-800 \mu \mathrm{g}$ of purified DARC protein.

Analysis of purified DARC in SDS-PAGE by CBB staining revealed the presence of a diffuse protein band with a molecular mass of 40 to $47 \mathrm{kDa}$ (Fig. 1a, lane 3) and faint bands, which may be contaminants or aggregated Duffy 
Table 1 Binding of lectins to purified DARC. +++ strong binding, ++ average binding, + weak binding, - no binding.

* - after desialylation, ** - after desialylation and degalactosylation
${ }^{a}$ Lectin specificities according to Wu et al. 2001 [59].

\begin{tabular}{|c|c|c|}
\hline Lectin & Recognized structure $^{a}$ & $\begin{array}{l}\text { Binding } \\
\text { to DARC }\end{array}$ \\
\hline $\begin{array}{l}\text { AAA } \\
\text { Aleuria aurantia agglutinin }\end{array}$ & $\alpha 1-6-$ Fuc $>\alpha 1-2,3-F u c$ & +++ \\
\hline $\begin{array}{l}\text { ConA (Concanavalin A) } \\
\text { Canavalia ensiformis agglutinin }\end{array}$ & 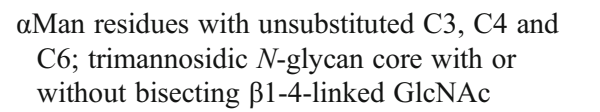 & + \\
\hline $\begin{array}{l}\text { DBA } \\
\text { Dolichos biflorus agglutinin }\end{array}$ & GalNAc residues & - \\
\hline $\begin{array}{l}\text { DSA } \\
\text { Datura stramonium agglutinin }\end{array}$ & $\begin{array}{l}\text { Gal } \beta 1-4 \mathrm{GlcNAc} \text { ( } N \text {-acetyllactosamine) residues, } \\
\text { tri- and tetraantennary complex-type } N \text {-glycan }\end{array}$ & +++ \\
\hline $\begin{array}{l}\text { GNA } \\
\text { Galanthus nivalis agglutinin }\end{array}$ & terminal $\alpha 1$-3-linked Man & - \\
\hline $\begin{array}{l}\text { GSL-I } \mathrm{B}_{4} \\
\text { Griffonia simplicifolia } \mathrm{I} \mathrm{B}_{4} \text { lectin }\end{array}$ & Gal 1 1-3Gal residues & - \\
\hline $\begin{array}{l}\text { GSL-II } \\
\text { Griffonia simplicifolia II lectin }\end{array}$ & GlcNAc residues & $+++* *$ \\
\hline $\begin{array}{l}\text { LCA } \\
\text { Lens culinaris agglutinin }\end{array}$ & $\begin{array}{l}\text { bi- and triantennary complex-type } N \text {-glycan with } \\
\text { a1-6-linked core fucose }\end{array}$ & +++ \\
\hline $\begin{array}{l}\text { MAA } \\
\text { Maackia amurensis agglutinin }\end{array}$ & $\alpha 2-3-\mathrm{Neu} 5 \mathrm{Ac}, \mathrm{SO}_{4}-3 \mathrm{Gal} \beta 1-4 \mathrm{GlcNAc}$ & ++ \\
\hline $\begin{array}{l}\text { PHA-E } \\
\text { Phaseolus vulgaris erythroagglutinin }\end{array}$ & $\begin{array}{l}\text { bi- and triantennary complex-type } N \text {-glycans with } \\
\text { bisecting GlcNAc }\end{array}$ & +++ \\
\hline $\begin{array}{l}\text { PHA-L } \\
\text { Phaseolus vulgaris leukoagglutinin }\end{array}$ & tri- and tetraantennary complex-type $N$-glycans & - \\
\hline $\begin{array}{l}\text { PSA } \\
\text { Pisum sativum agglutinin }\end{array}$ & $\begin{array}{l}\text { bi- and triantennary complex-type } N \text {-glycan with } \\
\text { a1-6-linked core fucose }\end{array}$ & +++ \\
\hline $\begin{array}{l}\text { PVL } \\
\text { Psathyrella velutina lectin }\end{array}$ & GlcNAc residues, $\alpha 2-3-\mathrm{Neu} 5 \mathrm{Ac}$ & +++ \\
\hline $\begin{array}{l}\text { RCA-I } \\
\text { Ricinus communis I agglutinin }\end{array}$ & terminal Gal & $+++*$ \\
\hline $\begin{array}{l}\text { SBA } \\
\text { Glycine } \max \text { (Soy bean) agglutinin }\end{array}$ & GalNAc residues & - \\
\hline $\begin{array}{l}\text { SNA } \\
\text { Sambucus nigra agglutinin }\end{array}$ & $\alpha 2-6-\mathrm{Neu} 5 \mathrm{Ac}$ & +++ \\
\hline $\begin{array}{l}\text { UEA-I } \\
\text { Ulex europaeus I agglutinin }\end{array}$ & $\alpha 1-2-F u c$ & - \\
\hline $\begin{array}{l}\text { WFA } \\
\text { Wisteria floribunda agglutinin }\end{array}$ & terminal $\alpha / \beta$ GalNAc & - \\
\hline $\begin{array}{l}\text { WGA } \\
\text { Triticum vulgaris (Wheat germ) agglutinin }\end{array}$ & GlcNAc $\beta 1-4$ polymers, Neu5Ac residues & ++ \\
\hline
\end{tabular}

protein. In western blotting analysis of affinity purified Duffy glycoprotein, the anti-Fy6 MoAb detected 40$47 \mathrm{kDa}$ Duffy monomer, accompanied by the diffused staining of the upper part of the blot (Fig. 1b). This pattern of staining is typical for the Duffy protein [21, 22, 25, 28, 29] and can represent self-association of this extremely hydrophobic protein into higher molecular weight oligomers. Analyzing the blots with anti-GPA and anti-Band 3 antibodies showed that purified Duffy protein did not contain GPA and contained only traces of Band 3 oligomers (Fig. 1b lane 3). Comparing the ghost lysate and the flow through from the affinity column showed the selective adsorption of most Duffy protein and no visible change in the content of total proteins, GPA or Band 3 (Fig. 1, lanes 1 and 2).

Secondary structure and interaction with antibodies

The circular dichroism (CD) spectrum of Duffy glycoprotein showed two negative maxima at $208 \mathrm{~nm}$ and $222 \mathrm{~nm}$ (Fig. 2), typical for a member of the GPCR family. Similar spectra were obtained for other chemokine receptors $[42$, 43]. The CD profile of purified DARC suggests a high 
Fig. 1 The efficiency of immunopurification of the Duffy antigen tested by SDSPAGE, followed by CBB staining (a) or immunoblotting (b). Lanes: 1 , dodecyl- $\beta$-maltoside solubilized ghosts; 2 , anti-Fy6 affinity flow through (unbound erythrocyte membrane extract); 3, anti-Fy6 affinity DFEDVWN peptide eluate (b) Proteins transferred to Immobilon-P membrane were identified with anti-Fy6, anti-GPA, anti-Band3 monoclonal antibodies. Lanes numbered 1, 2 and 3 were loaded with same material as used for CBB stained gel

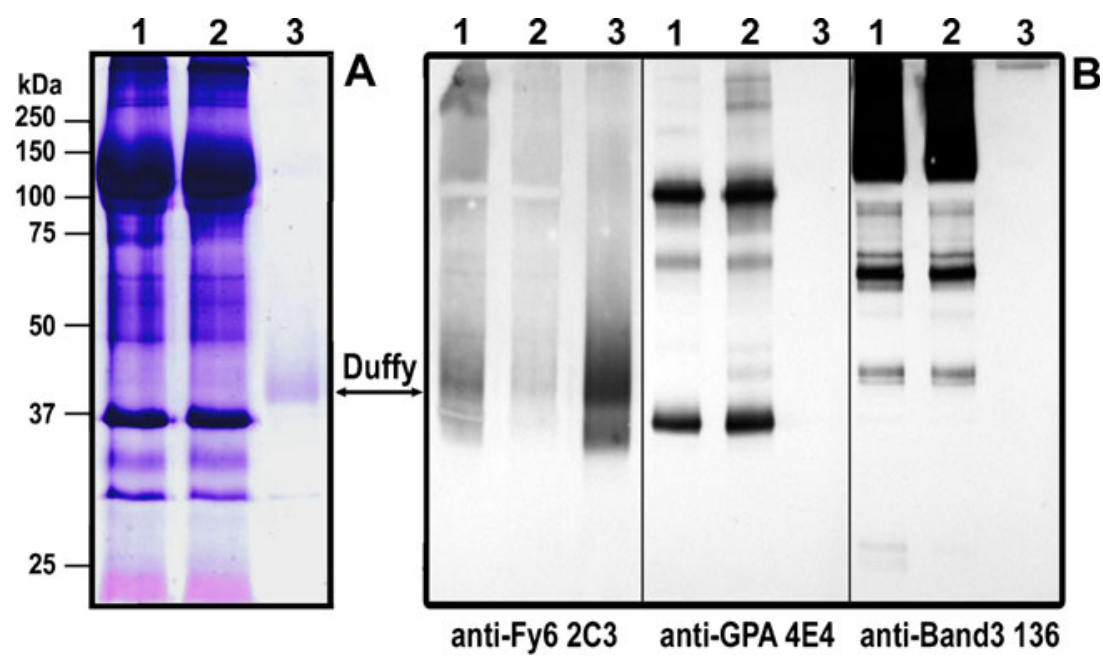

content of the $\alpha$-helical structure, which was calculated as $48 \%$ using the equation: $\% \alpha$-helix $=[\theta] 208 \mathrm{~nm}-$ $4000 / 33000-4000$ [44]. This result is very close to a theoretical $50 \% \alpha$-helix content for a GPCR and suggests that purified DARC retains the secondary structure characteristic of a chemokine receptor.

The ability of purified Duffy glycoprotein to interact with ligands was analyzed with chemiluminescent ELISA on DARC-coated plates using anti-Duffy antibodies. The antiDuffy antibodies chosen for the ELISA tests recognize different linear epitopes, Fy6, Fy3 and Fy ${ }^{\mathrm{a}}$. All anti-Duffy monoclonal antibodies, which were tested interacted with immunopurified DARC immobilized on ELISA plate (Fig. 3). This indicated that all analyzed antigenic determinants located in distinct regions of the Duffy molecule were accessible for the antibodies. As a negative control 4E4 monoclonal antibody recognizing amino acid residues 119-124 at the C-terminal part of glycophorin A was used. No reaction with this antibody was observed (Fig. 3)

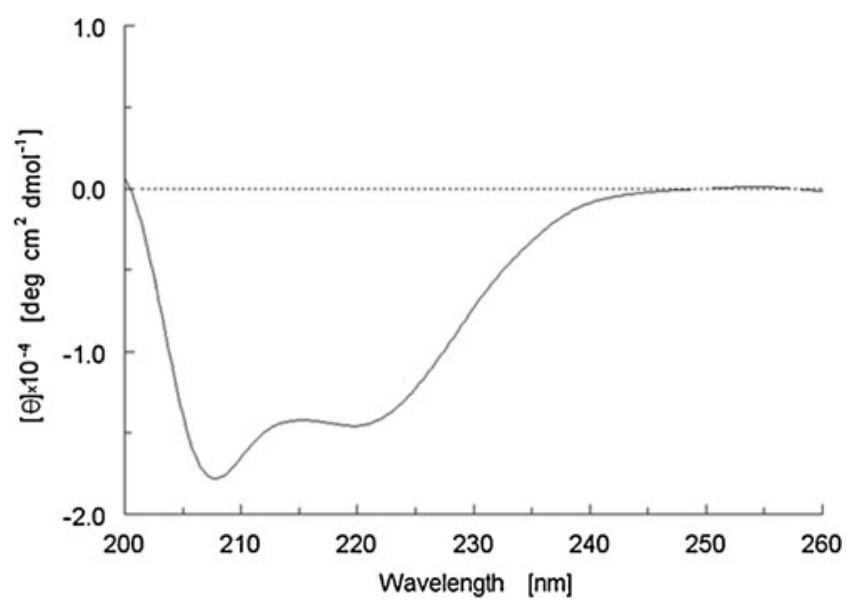

Fig. 2 Circular dichroism spectroscopy of purified Duffy glycoprotein (4.33 $\mu \mathrm{M}$ in $0.05 \%$ DDM, PBS). CD spectrum reveals two negative maxima at $208 \mathrm{~nm}$ and $222 \mathrm{~nm}$ characteristic for GPCR receptors confirming the absence of contamination of the purified DARC sample with GPA.

Analysis of DARC $N$-glycans by endoglycosidase digestion

To characterize the glycan part of DARC, purified Duffy glycoprotein was treated with glycosidases and the effects of digestion on molecular mass were assessed by western blotting. As shown in Fig. 4a digesting Duffy glycoprotein with PNGase F, which cleaves all $N$-linked oligosaccharides, resulted in a molecular mass change from $\sim 40-47 \mathrm{kDa}$ (native form) to $\sim 28-30 \mathrm{kDa}$ indicating that the molecular mass of the three DARC $N$-glycan chains is $\sim 18 \mathrm{kDa}$. In addition, bands representing higher molecular masses of $\sim 65-70 \mathrm{kDa}, \sim 130 \mathrm{kDa}$ and $\sim 250 \mathrm{kDa}$ (Fig. 4a, lane PNGase F) were also observed. These bands are probably products of oligomerisation of the Duffy glycoprotein resulting from the incubation with the enzyme at $37^{\circ} \mathrm{C}$ and may represent dimer, trimer, tetramer or high oligomers of deglycosylated Duffy protein. It cannot be excluded that removing the three $\mathrm{N}$-glycans from the polypeptide chain of DARC increases the potential of this glycoprotein to form aggregates. Treating the sample with endoglycosidase F1, removing high-mannose and hybrid type $N$-glycans, resulted in only partial digestion, which could be observed as a faint band corresponding to a molecular mass of about $30 \mathrm{kDa}$, close to that of a completely deglycosylated form of the protein. On the other hand, incubating the Duffy glycoprotein with endoglycosidase F2, cleaving high-mannose and biantennary complex-type $N$-glycans, had no effect on the molecular mass of DARC. Taken together this could suggest that Duffy glycoprotein does not contain high mannose chains, but a small number of DARC molecules present in the sample have hybrid-type $N$-glycans. Treating DARC samples with endoglycosidase F3, which cleaves bi- and triantennary complex-type $N$-glycans, resulted in shifting the molecular mass corresponding to the Duffy 
Fig. 3 Binding of anti-Duffy (anti-Fy6 i3A, anti-Fy3 MIMA 29, anti Fy ${ }^{\mathrm{a}}$ 5T72) monoclonal antibodies to the wells of ELISA plates coated with purified DARC. Binding of irrelevant antibody anti-GPA 4E4 was also analyzed. Binding was determined using HRP-labeled antibodies directed against mouse or human IgG. Chemiluminescent reaction was developed with SuperSignal ELISA Pico Chemiluminescent Substrate and measured on a Victor Light Microplate Luminometer. CPS - counts per second

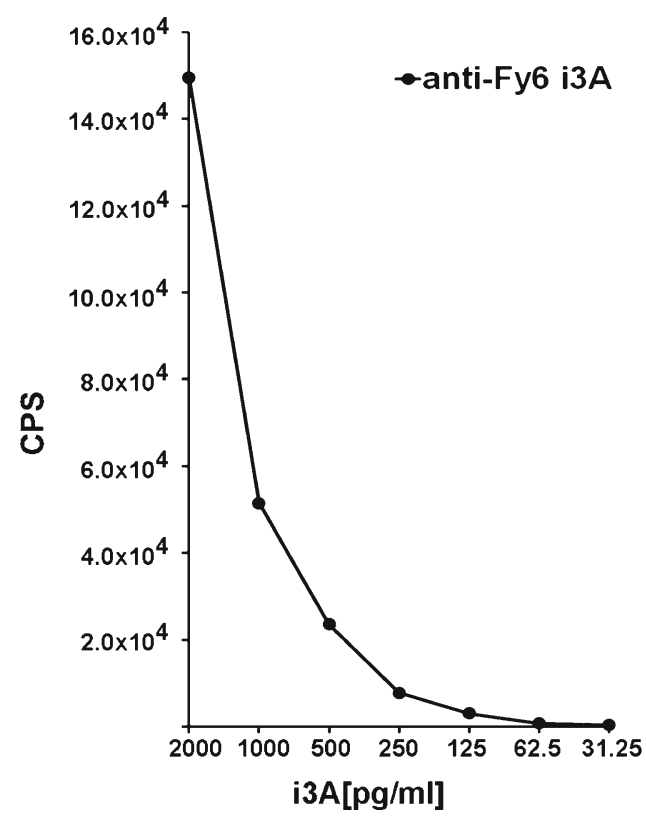

band to about $30 \mathrm{kDa}$, close to the protein mass after PNGase F digestion. This could suggest that most of the oligosaccharide chains of Duffy antigen are complex-type structures. The small difference in the electrophoretic mobility of DARC after PNGase F and endoglycosidase F3 treatment is difficult to explain. It does not depend on enzyme activity or concentration but it could be related to different sites of cleaving: PNGase F is hydrolyzing the intact $N$-glycans directly from asparagine of the polypeptide chain while endoglycosidase F3 cleaves the bond between two GlcNAc residues in the chitobiose core of $\mathrm{N}$-glycan. The removal of Duffy $N$-glycans due to PNGase F and endoglycosidase F3 digestion was confirmed by probing the digested DARC with Datura stramonium lectin. This lectin recognizes mostly complex-type $N$-glycans. We found that it strongly reacts with the recombinant form of the Duffy antigen [28] and with that from erythrocytes as well (Fig. 5b). No reaction with DSA was observed in western blotting after PNGase F and endoglycosidase F3 treatment (Fig. 4b).

To study the presence of $\mathrm{N}$-acetyllactosamine units in DARC oligosaccharides, we digested purified Duffy glycoprotein with endo- $\beta$-galactosidase, which releases the $\beta 1-4-$ linked galactose in unbranched repeating $\operatorname{GlcNAc} \beta(1-3)$ Gal $\beta(1-4)$ GlcNAc structures. After enzyme treatment a slight decrease in molecular mass of Duffy bands was observed in western blotting (Fig. 4a) suggesting the presence of a small population of the endo- $\beta$-galactosidase-sensitive carbohydrate chains in Duffy glycoprotein. Interestingly, after endo- $\beta$-galactosidase treatment, Duffy bands gave a strong signal with DSA (Fig. 4b), which binds specifically to $\mathrm{Gal} \beta(1-4)$ GlcNAc, suggesting that a certain number of $N$-acetyllactosamine units present in analyzed $N$-glycans might be resistant to enzyme digestion. This may be due to the degree of branching or fucosylation of oligosacharides or sulfation of galactose.

Analysis of human Duffy glycoprotein oligosaccharide chains with lectins

$N$-linked oligosaccharide chains of the human Duffy antigen from erythrocytes were analyzed by probing DARC glycoprotein with lectins in lectin blotting. Duffy glycoprotein was detected on the blots using anti-Duffy monoclonal antibody (2C3) and lectin blotting assays were performed in parallel. A positive reaction was found with SNA and MAA, which specifically recognize sialic acid linked $\alpha 2-6$ or $\alpha 2-3$ to galactose, respectively. To confirm the presence of both $\alpha 2-3$ and $\alpha 2-6$ sialic acid residues Duffy glycoprotein was digested with ABS (cleaves $\alpha 2-3,6,8,9$-linked Neu5Ac) and NDV (cleaves $\alpha 2-3,8$-linked Neu5Ac) sialidases and analyzed by western blotting. In immunoblotting with $2 \mathrm{C} 3 \mathrm{MoAb}$ a small molecular mass shift was observed after treating DARC with ABS or NDV sialidase. No reaction with MAA recognizing $\alpha 2-3$-linked sialic acid residues was observed in both digested samples, while SNA reacted with untreated and NDV-treated Duffy antigen (Fig. 4c). These results confirm the presence of $\alpha 2-6-$ and $\alpha 2-3$ linked sialic acid residues. The possible presence of sialic acids in $\alpha 2-8$ or $\alpha 2-9$ linkages in DARC from human erythrocytes cannot be excluded. However, a significant molecular mass shift after ABS digestion, which could result from the presence of such polymers, was not observed in western blotting developed with $2 \mathrm{C} 3 \mathrm{MoAb}$ or lectins. As shown in Fig. 5a the binding of SNA and MAA to Duffy antigen oligosaccharides was abolished after removing sialic acid from the blotted protein by mild acid hydrolysis. This confirmed the specificity of these interactions. 
Fig. 4 Western blotting analysis of purified Duffy glycoprotein treated with endoglycosidases or sialidases. Purified Duffy antigen treated with PNGase F, or

endoglycosidase F1, F2, or F3, or endo- $\beta$-galactosidase was identified with $2 \mathrm{C} 3$ anti-Fy 6 monoclonal antibody (a) or DSA agglutinin (b). Purified Duffy antigen treated with sialidase from Newcastle disease virus (NDV) or from Arthrobacter ureafaciens (ABS), was identified with $2 \mathrm{C} 3$ anti-Fy 6 monoclonal antibody or MAA and SNA agglutinins (c)
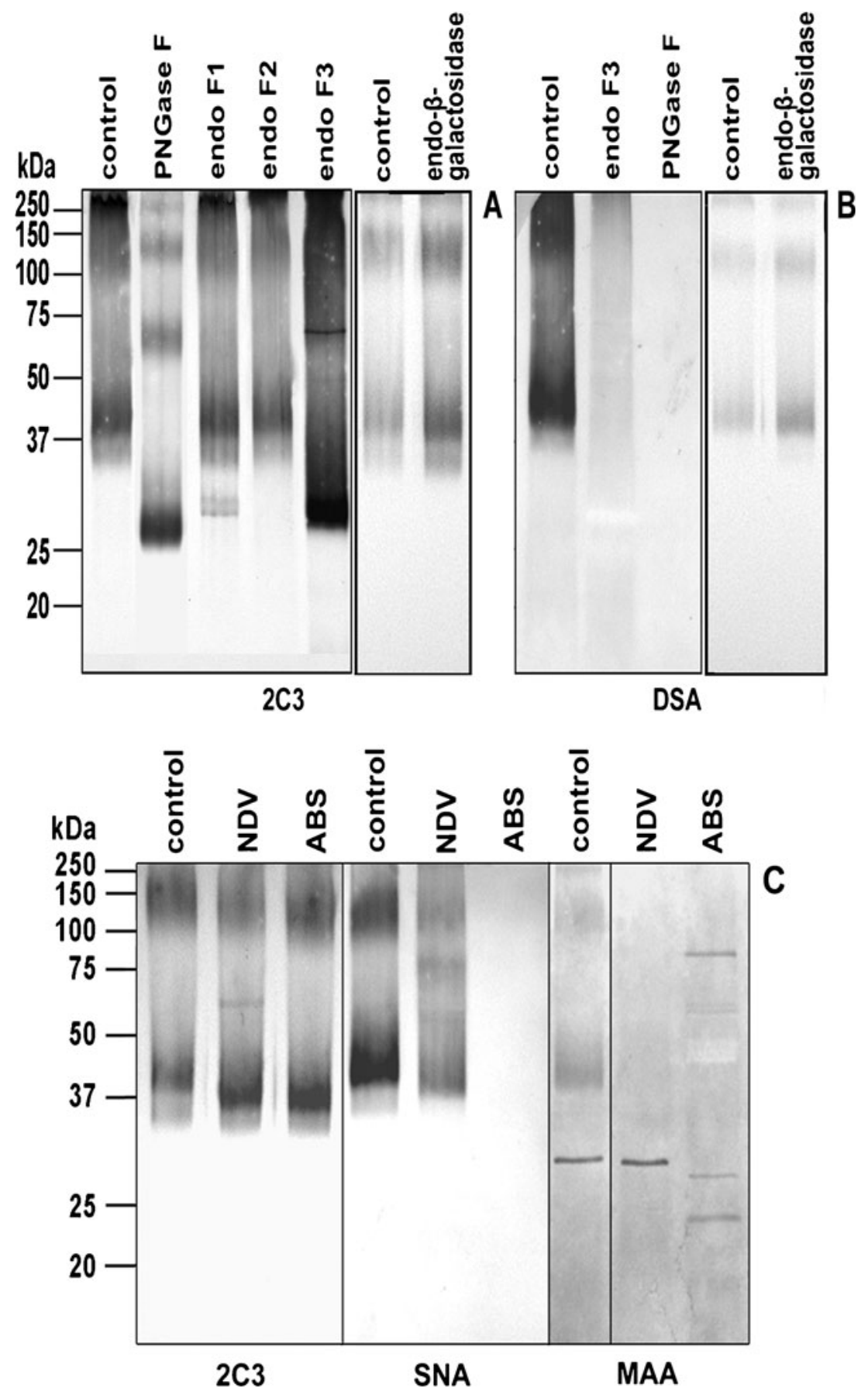

RCA, which is specific for terminal galactose residues, particularly in Gal $\beta 1-4$ GlcNAc units, reacted with the Duffy bands only after desialylation. Desialylation and degalactosylation, which removed terminal Gal residues from the blotted protein abolished the reaction with RCA and enabled a reaction with GlcNAc-recognizing GSL-II (Fig. 5a).

No reaction of Duffy glycoprotein was observed with GNA, which recognizes terminal $\alpha$-linked mannose residues typical for oligomannose and hybrid-type $N$-glycans. Only weak binding was observed for Concanavalin A
(Fig. 5a). This may confirm the lack of oligomannose chains among DARC glycans, suggested also by the results of endoglycosidase $\mathrm{F} 1$ and $\mathrm{F} 3$ digestion. ConA has the strongest affinity for $\alpha$-Man residues with unsubstituted $\mathrm{C} 3, \mathrm{C} 4$ and $\mathrm{C} 6$ but it also shows some weak interaction with the three mannose residues at the $N$-glycan core, however not in the presence of bisecting GlcNAc.

Other lectins such as DSA, PSA, PHA-E and PHA-L recognize more specific aspects of $\mathrm{N}$-glycan structures. The Duffy glycoprotein exhibited a strong interaction with DSA, which specifically binds $N$-acetyllactosamine units 
Fig. 5 Binding of sialic acid-, Gal-, GalNAc-, GlcNAc- and mannose-specific lectins to purified DARC and to DARC modified by desialylation ( $\star$ ) or degalactosylation $(\star \star)$ on the blot (a). Reaction of the blotted Duffy glycoprotein with lectins recognizing complex-type branched $N$-glycans (b). Binding of Aleuria aurantia and Lens culinaris agglutinins to purified DARC. After protein transfer and blocking the blots were incubated in the absence $(-)$ or presence $(+)$ of competing sugar: $0.7 \mathrm{M} \mathrm{L}$-fucose for AAA and $0.5 \mathrm{M}$ methyl $\alpha$-Dmannopyranoside for LCA (c)
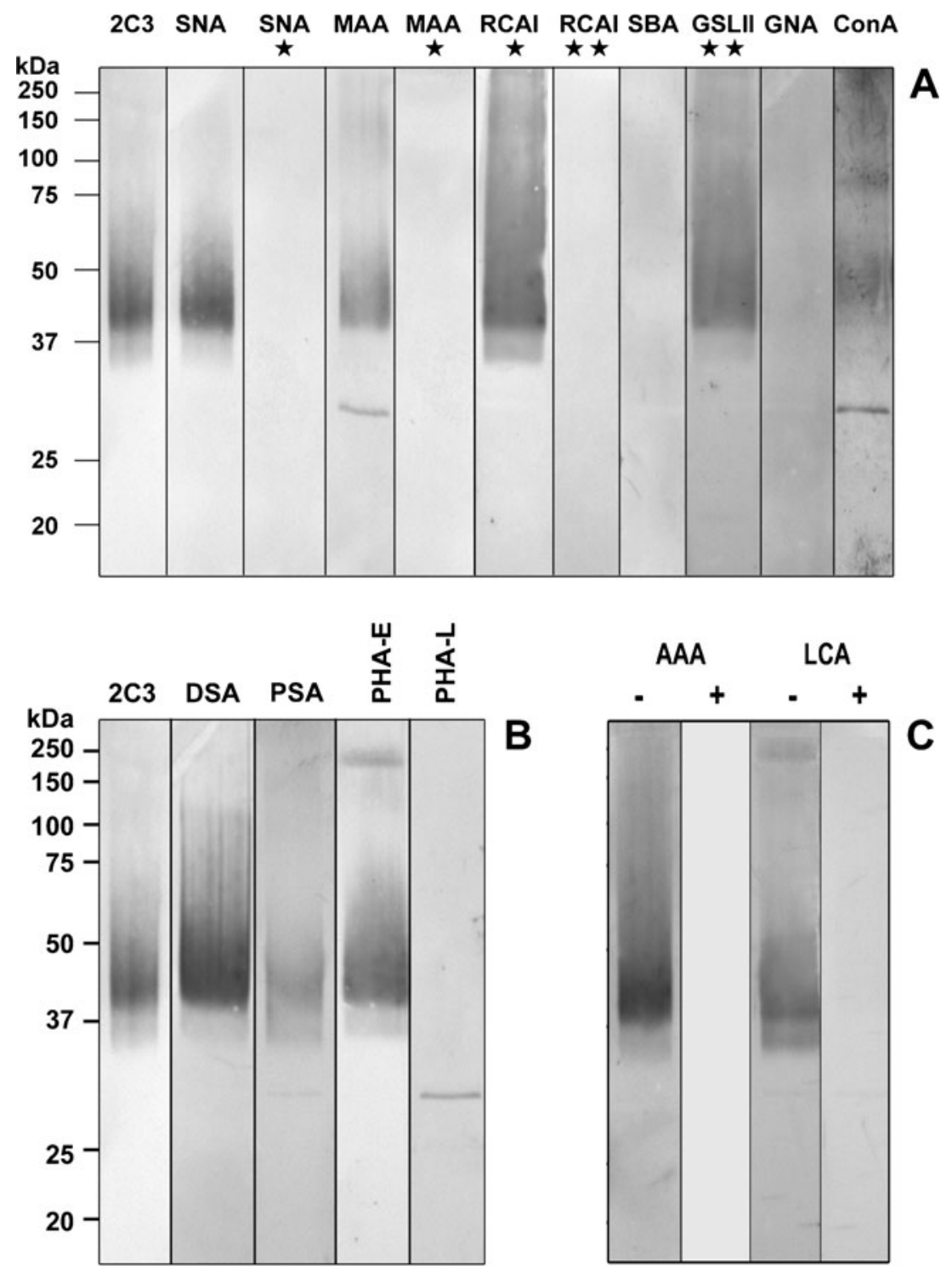

(Galß1-4GlcNAc) in complex-type or hybrid $N$-glycans (Fig. 5b). This has also been observed with recombinant DARC from transfected K562 cells [28]. Very strong binding of PHA-E, which binds "bisected" complex-type $\mathrm{N}$-glycans and the lack of binding of PHA-L specific for complex-type $N$-glycans containing 2,6-branched structure (Fig. 5b) suggested that native DARC oligosaccharides are bi- or triantennary complex-type $N$-glycans with bisecting GlcNAc, which confirmed results obtained by endoglycosidase F3 digestion. A strong reaction was also observed for PSA (Fig. 5b) and LCA (Fig. 5c) recognizing corefucosylated complex-type $N$-glycans. To verify the presence of L-fucose, often found in hybrid- and complextype $N$-glycan chains, AAA and UEA-I were used in lectin blotting. A very strong reaction with AAA (Fig. 5c), recognizing $\alpha 1-2-, \alpha 1-3-$ and particularly $\alpha 1-$ 6-linked Fuc, indicates the presence of a significant quantity of fucose in DARC oligosaccharides. UEA-I, which is specific for $\alpha 1-2$-linked Fuc, did not react with Duffy antigen. This implies that most of the fucose residues may be $\alpha 1$-6-linked to $N$-acetylglucosamine at the $N$-glycan core. This hypothesis is supported by the strong binding of LCA and PSA, which recognize bi- and triantennary complex-type $N$-glycans but require the presence of $\alpha 1-6$ core fucose for this interaction. The specificity of reaction with AAA and LCA was confirmed by preincubating the lectins with excess of competing sugars (L-fucose and $\alpha$-methyl-mannopyranoside respectively), which totally inhibited binding the lectins to Duffy (Fig. 5c). GalNAc-specific lectins DBA, SBA and WFA, as well as GSL-I, which recognize Gal $\alpha 1-3 \mathrm{Gal}$, showed no interaction with Duffy glycoprotein (not shown). We believe that the presence of these glycan structures in complex $N$-linked oligosaccharides of DARC from human erythrocytes is not very probable. The results of the lectinbinding analysis are summarized in Table 1. 


\section{Discussion}

Obtaining purified Duffy protein is very difficult due to its low content $\left(10-12 \times 10^{3}\right.$ copies per cell) on erythrocytes and strong tendency of native Duffy to form homo- and hetero-oligomers, which leads to great protein losses during purification $[21,22,24,25]$. The same applies to recombinant Duffy protein and chemokine receptors since there is no efficient system of expression. For these reasons, of over 20 chemokine receptors and chemokine binding proteins only a few molecules have been obtained in quantities sufficient to perform molecular characterization [39-43]. Recently, the crystal structure of the first chemokine receptor CXCR4 in complex with small molecular antagonists has been reported. On the basis of the results of crystallographic analysis the mechanism of CXCR4 interaction with its ligands was proposed [45].

A detailed description of the molecular structure of the Duffy glycoprotein is crucial for understanding the mechanisms of its interactions with ligands and explaining its biological role. In this study we undertook the effort to purify and characterize the native Duffy glycoprotein from human erythrocytes. We solubilized DARC under the same conditions as were previously applied for the isolation and purification of the functional atypical chemokine receptor D6 [39] and chemokine receptors CCR1 [41] and CXCR4 [40, 45]. This involved a combination of $1 \%$ DDM and $0.05 \%$ CHS in extraction buffer, which very effectively solubilizes the protein from cell membranes and prevents its self-aggregation. To purify Duffy glycoprotein from the detergent extract we used an immobilized anti-Duffy mouse monoclonal antibody for adsorption and a synthetic peptide DFEDVWN covering the sequence of the antibody epitope for elution of bound protein. This allowed us to obtain highly purified Duffy glycoprotein essentially free of other proteins of the RBC membrane. AntiFy6 antibodies were used as an affinity reagent to purify the Duffy antigen from Triton extract of red cell membranes [21, 24]. Recently, an immunoadsorbent prepared with anti-Fy6 recombinant CA52 dromedary antibody fragment and peptide containing epitope sequence for elution have been successfully used for the purification of a recombinant DARC in smallscale experiments [29]. The novelty of our method in relation to the previously described conditions for isolation and purification of Duffy antigen was the application of detergent DDM and CHS mixture, which help to maintain correctly folded protein structure after purification. We have shown this by $\mathrm{CD}$ measurements. Additionally, elution of bound Duffy protein with epitope peptide solution helps to keep protein in its native state since it is not exposed to harsh elution conditions commonly used for elution of immunoadsorbents.

Glycosylation is the most common form of posttranslational modification of proteins in eukaryotes and analysis of the protein sequence data bank reveals that significant proportions of proteins do contain sequence patterns suggesting that they might be glycosylated. To date, the glycosylation of few chemokine receptors and D6 atypical receptor has been reported. It was shown to be important for ligand binding and HIV entry through the CCR5 and CXCR4 receptors [46, 47] while it is not required for chemokines binding by DARC or D6 atypical chemokine receptor $[9$, $39,48]$. Glycosylation is significant for protein folding and stability and may be important for chemokine physiology, but the oligosaccharide chain structures of chemokine receptors are still unknown.

Erythrocyte membrane glycoproteins show different types of glycosylation but often are decorated with complex-type oligosaccharides with various degree of branching. Glycophorin A (GPA), an abundant sialoglycoprotein of RBCs is highly $O$-glycosylated and contains one $N$-linked chain per molecule. The major form of GPA $N$-glycan is a relatively short $\alpha 2-6$-sialylated biantennary chain with bisecting GlcNAc residue of molecular mass $\sim 2,400$ Da $[49,50]$. A minor fraction of GPA $\mathrm{N}$-glycan pool was found to contain blood group $\mathrm{ABH}$ epitopes [51]. On the other hand, the multimembrane spanning glycoproteins Band 3 (anion transporter) and Band 4.5 (glucose transporter Glut1) have large $N$-glycans with polyllactosamine-type antennae, which are major carriers of ABH blood group determinants [52-57]. The results of our study, i.e. lack of binding of lectins such as UEA-I, DBA, GSL-I, SBA, WFA to purified DARC, indicate the absence of ABH blood group epitopes in oligosaccharides of the Duffy antigen. However, it is possible that to detect only minute amounts of these carbohydrate structures more sensitive mass spectrometry methods would be necessary for greater precision and accuracy.

The results of this study obtained by means of lectins and endoglycosidase digestion indicate that the sugar chains of Duffy glycoprotein from red blood cells are mostly triantennary complex-type terminated with $\alpha 2-3$ - and $\alpha 2$-6-linked sialic acid residues with bisecting GlcNAc and $\alpha 1-6$-linked fucose at the core. There is no observed evidence suggesting the presence of oligomannose-type chains. The structures of DARC $N$-glycans may differ by number of lactosamine units in their antannae, degree of branching and some minor modifications such as the presence of bisecting GlcNAc or different combinations of terminal sialic acid residues. The decrease of apparent molecular mass of deglycosylated Duffy glycoprotein gives an average molecular mass of $\mathrm{N}$ glycans $\sim 6,000 \mathrm{Da}$ that strongly suggests that these glycans have antennae elongated by repeating lactosamine units and are more similar to $\mathrm{N}$-glycans of Band 3 and Band 4.5 than to GPA $N$-glycan.

This is also supported by the results of digestion with endo- $\beta$-galactosidase and strong reaction with DSA lectin, however the oligosaccharide structure recognized by DSA 
was not readily accessible to endo- $\beta$-galactosidase therefore DSA reacted strongly after enzyme digestion. In contrast, linear $N$-acetyllactosaminyl glycans present in Band 3 and Band 4.5 are released by endo- $\beta$-galactosidase [58]. Presence of poly- $N$-acetyllactosamine units in native Duffy antigen from human erythrocytes is highly possible but these oligosaccharides may differ from those of Band 3 and Band 4.5 in branching or sulfation of galactose residue $[52,55]$. Since the molecular mass shift observed for DARC after treatment with endo- $\beta$ galactosidase is not very significant, the lactosamine units present in this glycoprotein are possibly not as extended as the structures found in Band 3.

In our earlier studies we showed that recombinant Duffy glycoprotein has $N$-glycans attached at the three potential glycosylation sites at Asn16, Asn27 and Asn33 and the $N$ oligosaccharide chains were characterized [27, 28]. A comparison of $\mathrm{N}$-glycans from recombinant and native Duffy glycoprotein indicates that both are heterogenic, mainly complex-type $N$-oligosaccharide chains with varying degree of branching. Minor differences in sugar moieties structure concern the type of sialic acid linkage. Recombinant Duffy $N$-glycans lack sialic acids in $\alpha 2-3$ linkage while native Duffy glycoprotein contains $\alpha 2-6-$ and $\alpha 2-3$-linked sialic acid residues.

In conclusion, DARC was solubilized with $n$-dodecyl- $\beta$ D-maltoside from human erythrocyte membranes and purified using immunoaffinity chromatography. Using this procedure $500-800 \mu \mathrm{g}$ of purified DARC can be obtained from detergent solubilized $200 \mathrm{ml}$ of erythrocyte membranes. Purified DARC is recognized by several anti-Duffy monoclonal antibodies directed against different parts of the DARC polypeptide chain. The expected high content of $\alpha$ helical structure was confirmed by CD measurements. Oligosaccharide chains of DARC were characterized by means of lectins and endoglycosidase digestion. Duffy $N$-glycans are bi- and/or triantennary complex-type, terminated with $\alpha 2-3-$ and $\alpha 2-6$-linked sialic acid residues with bisecting GlcNAc and $\alpha 1-6$-linked fucose at the core. This type of large oligosaccharide chain may be characteristic for multimembrane spanning glycoproteins of red blood cells membrane. These findings make a significant contribution to the description of Duffy glycan moieties.

Acknowledgements We would like to thank Dr. E. Klausa and Dr. S. Bochenek from the Regional Centre of Transfusion Medicine and Blood Bank, Wrocław, Poland for the samples of human erythrocytes. This study was supported by grant no. N N401 536640 from the Ministry of Science and Higher Education of Poland.

Open Access This article is distributed under the terms of the Creative Commons Attribution Noncommercial License which permits any noncommercial use, distribution, and reproduction in any medium, provided the original author(s) and source are credited.

\section{References}

1. Hadley, T.J., Peiper, S.C.: From malaria to chemokine receptor: the emerging physiologic role of the Duffy blood group antigen. Blood 89, 3077-3091 (1997)

2. Pogo, A.O., Chaudhuri, A.: The Duffy protein: A malarial and chemokine receptor. Sem. Hematol. 37, 122-129 (2000)

3. Rot, A., Horuk, R.: The Duffy antigen receptor for chemokines. In: Handel, T.M., Hamel, D.J. (eds.) Methods in Enzymology, vol.461, Chemokines, Part B, pp. 191-207. Elsevier, USA (2009)

4. Wasniowska, K., Blanchard, D., Janvier, D., Wang, Z.X., Peiper, S. C., Hadley, T.J., Lisowska, E.: Identification of the Fy6 epitope recognized by two monoclonal antibodies in the $\mathrm{N}$-terminal extracellular portion of the Duffy antigen receptor for chemokines. Mol. Immunol 33, 917-923 (1996)

5. Wasniowska, K., Petit-LeRoux, Y., Tournamille, C., Le van Kim, C., Cartron, J.P., Colin, Y., Lisowska, E., Blanchard, D.: Structural characterization of the epitope recognized by the new anti-Fy6 monoclonal antibody NaM 185-2C3. Transfus. Med 12, 205-211 (2002)

6. Wasniowska, K., Lisowska, E., Halverson, G.R., Chaudhuri, A., Reid, M.E.: The Fya, Fy6 and Fy3 epitopes of the Duffy blood group system recognized by new monoclonal antibodies: identification of a linear Fy3 epitope. Br. J. Haematol. 124, 118-122 (2004)

7. Horuk, R., Chitnis, C.E., Darbonne, W.C., Colby, T.J., Rybicki, A., Hadley, T.J., Miller, L.H.: A receptor for malarial parasite Plasmodium vivax: The erythrocyte chemokine receptor. Science 261, 1182-1184 (1993)

8. Lu, Z.H., Wang, Z.X., Horuk, R., Hesselgesser, J., Lou, Y.C., Hadley, T.J., Peiper, S.C.: The promiscuous chemokine binding profile of the Duffy antigen/receptor for chemokines is primarily localized to sequences in the amino-terminal domain. J. Biol. Chem. 270, 26239-26245 (1995)

9. Tournamille, C., Filipe, A., Wasniowska, K., Gane, P., Lisowska, E., Cartron, J.P., Colin, Y., Le Van Kim, C.: Structure-function analysis of the extracellular domains of the Duffy antigen/receptor for chemokines: characterization of antibody and chemokine binding sites. Br. J. Haematol 6, 1014-1023 (2003)

10. Choe, H., Moore, M.J., Owens, C.M., Wright, P.L., Vasilieva, N., Li, W., Singh, A.P., Shakri, R., Chitnis, C.E., Farzan, M.: Sulphated tyrosines mediate association of chemokines and Plasmodium vivax Duffy binding protein with the Duffy antigen/receptor for chemokines (DARC). Mol. Microbiol. 55, 1413-1422 (2005)

11. Gardner, L., Patterson, A.M., Ashton, B.A., Stone, M.A., Middleton, J.: The human Duffy antigen binds selected inflammatory but not homeostatic chemokines. Biochem. Biophys. Res. Commun. 321, 306-312 (2004)

12. Nibbs, R., Graham, G., Rot, A.: Chemokines on the move: control by the chemokine "interceptors" Duffy blood group antigen and D6. Semin. Immunol. 15, 287-294 (2003)

13. Grodecka, M., Wasniowska, K.: Interceptors-"silent" chemokine receptors. Postepy Hig. Med. Dosw. (Online) 61, 231-239 (2007)

14. Graham, G.J.: D6 and the atypical chemokine receptor family: novel regulators of immune and inflammatory processes. Eur. J. Immunol. 39, 342-351 (2009)

15. Ulvmar, M.H., Hub, E., Rot, A.: Atypical chemokine receptors. Exp Cell Res. 317, 556-568 (2011)

16. Darbonne, W.C., Rice, G.C., Mohler, M.A., Apple, T., Hébert, C. A., Valente, A.J., Baker, J.B.: Red blood cells are a sink for interleukin 8, a leukocyte chemotaxin. J. Clin. Invest. 88, 13621369 (1991)

17. Pruenster, M., Mudde, L., Bombosi, P., Dimitrova, S., Zsak, M., Middleton, J., Richmond, A., Graham, G.J., Segerer, S., Nibbs, R. J., Rot, A.: The Duffy antigen receptor for chemokines transports chemokines and supports their promigratory activity. Nat. Immunol. 10, 101-108 (2009) 
18. Shen, H., Schuster, R., Stringer, K.F., Waltz, S.E., Lentsch, A.B.: The Duffy antigen/receptor for chemokines (DARC) regulates prostate tumor growth. FASEB J. 20, 59-64 (2006)

19. Wang, J., Ou, Z.L., Hou, Y.F., Luo, J.M., Shen, Z.Z., Ding, J., Shao, Z.M.: Enhanced expression of Duffy antigen receptor for chemokines by breast cancer cells attenuates growth and metastasis potential. Oncogene 25, 7201-7211 (2006)

20. Segerer, S., Jedlicka, J., Wüthrich, R.P.: Atypical chemokine receptors in renal inflammation. Nephron Exp. Nephrol. 115, 8995 (2010)

21. Chaudhuri, A., Zbrzezna, V., Johnson, C., Nichols, M., Rubinstein, P., Marsh, W.L., Pogo, A.O.: Purification and characterization of an erythrocyte membrane protein complex carrying Duffy blood group antigenicity. Possible receptor for Plasmodium vivax and Plasmodium knowlesi malaria parasite. J. Biol. Chem. 264, 1377013774 (1989)

22. Wasniowska, K., Eichenberger, P., Kugele, F., Hadley, T.J.: Purification of a $28 \mathrm{kDa}$ non-aggregating tryptic peptide of the Duffy blood group protein. Biochem. Biophys. Res. Commun. 192, 366372 (1993)

23. Horuk, R., Colby, T.J., Darbonne, W.C., Schall, T.J., Neote, K.: The human erythrocyte inflammatory peptide (chemokine) receptor. Biochemical characterization, solubilization, and development of a binding assay for the soluble receptor. Biochemistry 32, 5733-5738 (199)

24. Riwom, S., Janvier, D., Navenot, J.M., Benbunan, M., Muller, J.Y., Blanchard, D.: Production of a new murine monoclonal antibody with Fy6 specificity and characterization of the immunopurified Nglycosylated Duffy-active molecule. Vox Sang. 66, 61-67 (1994)

25. Hadley, T.J., David, P.H., McGinniss, M.H., Miller, L.H.: Identification of an erythrocyte component carrying the Duffy blood group Fy antigen. Science 223, 597-599 (1984)

26. Tanner, M.J., Anstee, D.J., Mallinson, G., Ridgwell, K., Martin, P. G., Avent, N.D., Parsons, S.F.: Effect of endoglycosidase Fpeptidyl N-glycosidase F preparations on the surface components of the human erythrocyte. Carbohydr. Res. 178, 203-212 (1988)

27. Czerwinski, M., Kern, J., Grodecka, M., Paprocka, M., KropWatorek, A., Wasniowska, K.: Mutational analysis of the Nglycosylation sites of Duffy antigen/receptor for chemokines. Biochem. Biophys. Res. Commun. 356, 816-821 (2007)

28. Grodecka, M., Czerwinski, M., Duk, M., Lisowska, E., Wasniowska, $\mathrm{K}$. : Analysis of recombinant Duffy protein-linked N-glycans using lectins and glycosidases. Acta Biochim. Pol. 57, 49-53 (2010)

29. Smolarek, D., Hattab, C., Hassanzadeh-Ghassabeh, G., Cochet, S., Gutiérrez, C., de Brevern, A.G., Udomsangpetch, R., Picot, J., Grodecka, M., Wasniowska, K., Muyldermans, S., Colin, Y., Le Van Kim, C., Czerwinski, M., Bertrand, O.: A recombinant dromedary antibody fragment (VHH or nanobody) directed against human Duffy antigen receptor for chemokines. Cell Mol. Life Sci 67, 3371-3387 (2010)

30. Rasamoelisolo, M., Czerwinski, M., Bruneau, V., Lisowska, E., Blanchard, D.: Fine characterization of a series of new monoclonal antibodies directed against glycophorin A. Vox Sang. 72, 185-191 (1997)

31. Czerwinski, M., Wasniowska, K., Steuden, I., Duk, M., Więdłocha, A., Lisowska, E.: Degradation of the human erythrocyte membrane band 3 studied with monoclonal antibody directed against an epitope on the cytoplasmic fragment of band 3. Eur. J. Biochem. 174, 647-654 (1988)

32. Steck, T.L., Weinstein, R.S., Strauss, J.H., Wallach, D.F.H.: Insideout red cell membrane vesicles: preparation and purification. Science 168, 255-257 (1970)

33. Rosenberry, T.L., Chen, J.F., Lee, M.M., Moulton, T.A., Onigman, P.: Large scale isolation of human erythrocyte membranes by high volume molecular filtration. J. Biochem. Biophys. Methods 4, 39 48 (1981)
34. Smith, P.K., Krohn, R.I., Hermanson, G.T., Mallia, A.K., Gartner, F.H., Provenzano, M.D., Fujimoto, E.K., Goeke, N.M., Olson, B. J., Klenk, D.C.: Measurement of protein using bicinchoninic acid. Anal. Biochem. 150, 76-85 (1985)

35. Laemmli, U.K.: Cleavage of structural proteins during the assembly of the head of bacteriophage T4. Nature 227, 680-685 (1970)

36. Royle, L., Radcliffe, C.M., Dwek, R.A., Rudd, P.M.: Detailed structural analysis of $\mathrm{N}$-glycans released from glycoproteins in SDS-PAGE gel bands using HPLC combined with exoglycosidase array digestions. Methods Mol. Biol. 347, 125-143 (2006)

37. Towbin, H., Staehelin, T., Gordon, J.: Electrophoretic transfer of proteins from polyacrylamide gel to nitrocellulose sheets: Procedure and some applications. Proc. Natl. Acad. Sci. 76, 4350-4354 (1979)

38. Wu, A.M., Lisowska, E., Duk, M., Yang, Z.: Lectins as tools in glycoconjugate research. Glycoconj. J. 26, 899-913 (2008)

39. Blackburn, P.E., Simpson, C.V., Nibbs, R.J., O'Hara, M., Booth, R., Poulos, J., Isaacs, N.W., Graham, G.J.: Purification and biochemical characterization of the D6 chemokine receptor. Biochem J. 379, 263-272 (2004)

40. Dukkipati, A., Vaclavikova, J., Waghray, D., Garcia, K.C.: In vitro reconstitution and preparative purification of complexes between the chemokine receptor CXCR4 and its ligands SDF-1alpha, gp120CD4 and AMD3100. Protein Expr. Purif. 50, 203-214 (2006)

41. Allen, S.J., Ribeiro, S., Horuk, R., Handel, T.M.: Expression, purification and in vitro functional reconstitution of the chemokine receptor CCR1. Protein Expr. Purif. 66, 73-81 (2009)

42. Nisius, L., Rogowski, M., Vangelista, L., Grzesiek, S.: Large-scale expression and purification of the major HIV-1 coreceptor CCR5 and characterization of its interaction with RANTES. Protein Expr. Purif. 61, 155-162 (2008)

43. Ren, H., Yu, D., Ge, B., Cook, B., Xu, Z., Zhang, S.: High-level production, solubilization and purification of synthetic human GPCR chemokine receptors CCR5, CCR3, CXCR4 and CX3CR1. PLoS One (Online) 4, e4509 (2009)

44. Greenfield, N., Fasman, G.D.: Computed circular dichroism spectra for the evaluation of protein conformation. Biochemistry 8 , 4108-4116 (1969)

45. Wu, B., Chien, E.Y., Mol, C.D., Fenalti, G., Liu, W., Katritch, V., Abagyan, R., Brooun, A., Wells, P., Bi, F.C., Hamel, D.J., Kuhn, P., Handel, T.M., Cherezov, V., Stevens, R.C.: Structures of the CXCR4 chemokine GPCR with small-molecule and cyclic peptide antagonists. Science 330, 1066-1071 (2010)

46. Bannert, N., Craig, S., Farzan, M., Sogah, D., Santo, N.V., Choe, H., Sodroski, J.: Sialylated O-glycans and sulfated tyrosines in the $\mathrm{NH} 2$-terminal domain of $\mathrm{CC}$ chemokine receptor 5 contribute to high affinity binding of chemokines. J. Exp. Med. 194, 1661-1673 (2001)

47. Huskens, D., Princen, K., Schreiber, M., Schols, D.: The role of Nglycosylation sites on the CXCR4 receptor for CXCL-12 binding and signaling and X4 HIV-1 viral infectivity. Virology 363, 280287 (2007)

48. Wasniowska, K., Czerwinski, M., Jachymek, W., Lisowska, E.: Expression and binding properties of a soluble chimeric protein containing the N-terminal domain of the Duffy antigen. Biochem. Biophys. Res. Commun. 273, 705-711 (2000)

49. Irimura, T., Tsuji, T., Tagami, S., Yamamoto, K., Osawa, T.: Structure of a complex-type sugar chain of human glycophorin A. Biochemistry 20, 560-566 (1981)

50. Yoshima, H., Furthmayr, H., Kobata, A.: Structures of the asparagine-linked sugar chains of glycophorin A. J. Biol. Chem. 255, 9713-9718 (1980)

51. Fredriksson, S.A., Podbielska, M., Nilsson, B., Krotkiewska, B., Lisowska, E., Krotkiewski, H.: ABH blood group antigens in Nglycan of human glycophorin A. Arch. Biochem. Biophys. 498, $127-135$ (2010) 
52. Fukuda, M., Dell, A., Oates, J.E., Fukuda, M.N.: Structure of branched lactosaminoglycan, the carbohydrate moiety of band 3 isolated from adult human erythrocytes. J. Biol. Chem. 259, 826082673 (1984)

53. Tsuji, T., Irimura, T., Osawa, T.: The carbohydrate moiety of band 3 glycoprotein of human erythrocyte membranes. Structures of lower molecular weight oligosaccharides. J. Biol. Chem. 256, 10497-10502 (1981)

54. Vitala, J., Finne, J., Krusius, T.: Blood group A and H determinants in polyglycosyl peptides of A1 and A2 erytheocytes. Eur. J. Biochem. 126, 401-406 (1982)

55. Endo, T., Kasahara, M., Kobata, A.: Structure of the asparaginelinked sugar chain of glucose transporter from human erythrocytes. Biochemistry 29, 9126-9134 (1980)
56. Krusius, T., Finne, J., Rauvala, H.: The poly(glycosyl) chains of glycoproteins. Characterization of a novel type of glycoprotein saccharides from human erythrocyte membrane. Eur. J. Biochem. 92, 289-300 (1978)

57. Anstee, D.J.: The functional importance of blood group-active molecules in human red blood cells. Vox. Sang. 100, 140-149 (2011)

58. Fukuda, M.N., Fukuda, M., Hakomori, S.: Cell surface modification by Endo- $\beta$-galactosidase. Change of blood group activities and release of oligosaccharides from glycoproteins and glycosphingoklipids of human erythrocytes. J. Biol. Chem. 254, 5458-5465 (1979)

59. Wu, A.M., Song, S.C., Tsai, M.S., Herp, A.: A guide to the carbohydrate specificities of applied lectins-2 (updated in 2000). Adv. Exp. Med. Biol. 491, 551-585 (2001) 